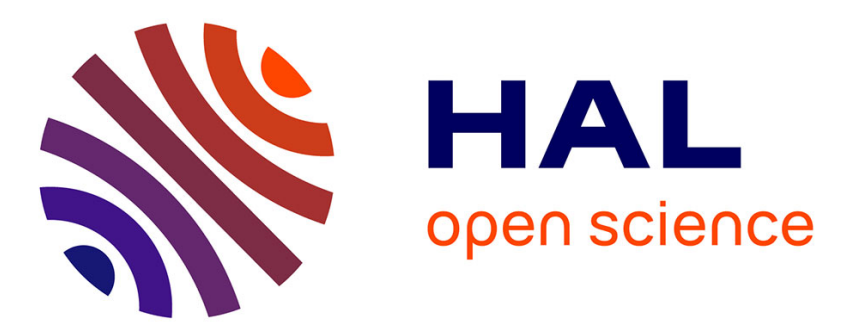

\title{
Internal Stress Analysis for the Damage Study of a 16MND5 Bainitic Steel
}

\author{
Raphaël Pesci, Karim Inal, Marcel Berveiller, Jean-Lu Lebrun
}

\section{To cite this version:}

Raphaël Pesci, Karim Inal, Marcel Berveiller, Jean-Lu Lebrun. Internal Stress Analysis for the Damage Study of a 16MND5 Bainitic Steel. Materials Science Forum, 2002, 404-407, pp.641-646. 10.4028/www.scientific.net/MSF.404-407.641 . hal-01245099

\section{HAL Id: hal-01245099 \\ https://hal.science/hal-01245099}

Submitted on 16 Dec 2015

HAL is a multi-disciplinary open access archive for the deposit and dissemination of scientific research documents, whether they are published or not. The documents may come from teaching and research institutions in France or abroad, or from public or private research centers.
L'archive ouverte pluridisciplinaire $\mathbf{H A L}$, est destinée au dépôt et à la diffusion de documents scientifiques de niveau recherche, publiés ou non, émanant des établissements d'enseignement et de recherche français ou étrangers, des laboratoires publics ou privés. 


\title{
Internal Stress Analysis for the Damage Study of a 16MND5 Bainitic Steel
}

\author{
Pesci R. ${ }^{1}$, Inal K. ${ }^{1}$, Berveiller M. ${ }^{1}$ And Lebrun J.L. ${ }^{2}$ \\ 'LPMM UMR CNRS 7554 - Ecole Nationale Supérieure des Arts et Métiers \\ 4, avenue Augustin Fresnel Technopôle Metz 200057078 Metz cedex 3 - France \\ ${ }^{2}$ LPMI - Ecole Nationale Supérieure des Arts et Métiers \\ 2, boulevard du Ronceray BP3525 49035 Angers cedex - France
}

Keywords: Bainite; Fracture mechanisms; Internal stresses; X-ray diffraction; Scanning Electron Microscope.

\begin{abstract}
The behavior and the fracture mechanisms of the 16MND5 bainitic pressure vessel steel are studied using a local approach of fracture on a crystallographic scale. A series of tensile tests are performed on the material at various temperatures ranging from $-196^{\circ} \mathrm{C}$ to $-60^{\circ} \mathrm{C}$ : the damage is observed with a Scanning Electron Microscope (SEM) while the residual stresses in the ferritic phase are determined by using the X-Ray Diffraction (XRD), never exceeding -150 MPa in compression. Thanks to these measurements, each stress value can be associated with a microscopic observation in order to couple the behavior of the material with the damage at various temperatures.
\end{abstract}

\section{Introduction}

E.D.F. launched an experimental and numerical research program several years ago, in order to analyze the behavior and the fracture mechanisms of the 16MND5 bainitic steel, and especially the influence of toughness in relation to temperature. The present study is part of this program, and aims at a local approach of fracture on a crystallographic scale, in the lower part of the ductile-to-brittle transition region and at lower temperatures.

The material, which is similar to A508 cl. 3 is a two-phase bainitic steel (ferrite and cementite): it has a complex microstructure composed of laths and packets within prior austenite grains, which makes it difficult to determine characteristic microstructural length. Defining the effective grain size is very important in order to determine the bainite behavior: the misorientation at the boundaries, which can act as a barrier to the crack propagation [1], has to be taken into account. The crack-initiation and crack-growth phenomena have been quite thoroughly analyzed on the macroscopic scale, but the mechanisms linked to the temperature effects remain to be studied ([2], [3], [4] and [5]). There have been many observations of post-mortem specimens (after failure [6]), but few have been done on the microscopic scale: even if some models exist, more testing remains to be done. The initiation sites are still too vaguely understood because only a few authors have studied the implied mechanisms on a crystallographic scale: no in-situ testing has been realized either.

The XRD is here used to determine internal stresses within the material: it is a highly efficient analytical tool since it gives a selective information in each phase (strain of the diffracting volume, crystalline orientation, hardening). Based on the measurement of the crystal lattice strains of each phase, from which one can deduce the stress tensor thanks to the $\sin ^{2} \psi$-method, it enables to understand the phenomena occurring in the multiphase material. No diffraction measurements have been realized yet on bainite, but pearlite is better known, since authors like Ruppersberg [7] and Belassel [8] have studied, in particular, the stress distribution into this material. The experimental part of the study enables to couple the observation of the material at different temperatures with the determined stresses, in order to establish damage criteria [9]. Each result is compared to what has already been observed with the SEM on the microscopic scale: the existing theories are thus more thoroughly defined, and more information on the various fracture mechanisms observed on the crystallographic scale are gathered. 


\section{Experimental procedures}

\subsection{Material}

The studied material is a low alloy steel 16MND5 (similar to A508 cl. 3). It is used in pressurized water reactors: the sample was taken at $3 / 4$ thickness. Its chemical composition is given in table 1 .

\begin{tabular}{|c|c|c|c|c|c|c|c|}
\hline C & S & P & Mn & Si & Ni & Cr & Mo \\
\hline 0,159 & 0,008 & 0,005 & 1,37 & 0,24 & 0,70 & 0,17 & 0,50 \\
\hline \hline $\mathrm{V}$ & $\mathrm{Cu}$ & $\mathrm{Co}$ & $\mathrm{Al}$ & $\mathrm{N}$ & $\mathrm{O}$ [ppm] & Sn [ppm] & As [ppm] \\
\hline$<0,01$ & 0,06 & $<0,01$ & 0,023 & 0,007 & $35-36$ & 50 & 160 \\
\hline
\end{tabular}

Table 1. Chemical composition of the 16MND5 bainitic steel (weight percentage, iron balance)

The sample underwent the following heat treatments:

a two austenizations at $865^{\circ} \mathrm{C} / 895^{\circ} \mathrm{C}$ during $4 \mathrm{~h} 40$ followed by water quench, in order to produce a bainitic microstructure,

a tempering at $630^{\circ} \mathrm{C} / 645^{\circ} \mathrm{C}$ during $7 \mathrm{~h} 30$ to improve the material's toughness,

a a stress-relief treatment (maintained at $610^{\circ} \mathrm{C}$ during $8 \mathrm{~h}$ ), in order to remove the residual stresses from the material.
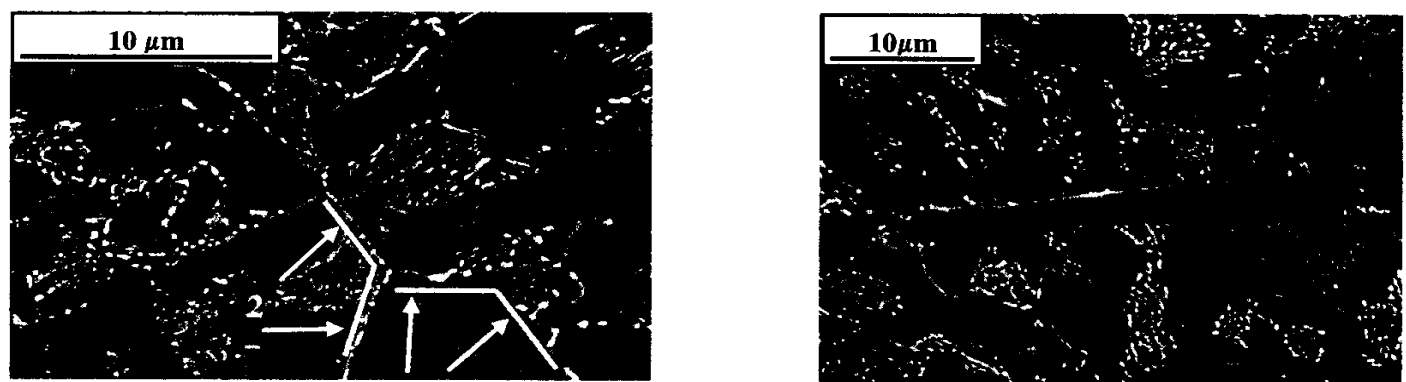

Fig.1. SEM micrographs showing the microstructure of bainite

1- Ferrite with cementite precipitates; 2- Former austenitic grain boundaries; 3- Manganese sulfide inclusion

The microstructure thus obtained is tempered bainite (fig.1). The ferritic matrix contains many carbides, mainly under the form of cementite precipitates, as cementite needles (in superior bainite) or as cementite spheres (in inferior bainite): their characteristic dimension is of the order of $0,1 \mu \mathrm{m}$. The metallographic examination reveals the presence of Manganese Sulfide (MnS) inclusions (volume fraction inferior to $1 \%$ ) of various types:

a spherical MnS inclusions (diameter generally inferior to $20 \mu \mathrm{m}$ ),

a elongated $\mathrm{MnS}$ inclusions (from $20 \mu \mathrm{m}$ to $70 \mu \mathrm{m}$ ),

a clusters of $\mathrm{MnS}$ inclusions (composed of several spherical or elongated MnS inclusions).

Other carbides are also present at the former austenitic grain boundaries, the size of which varies from $40 \mu \mathrm{m}$ to $80 \mu \mathrm{m}$.

The resilience curve for this steel was realized on a wide range of temperatures $\left[-196^{\circ} \mathrm{C} ; 300^{\circ} \mathrm{C}\right]$, as seen in figure 2: it shows a great variety of results in the ductile-to-brittle transition region, which varies from $-100^{\circ} \mathrm{C}$ to $60^{\circ} \mathrm{C}$. The present study concerns the low temperatures and the lower part of the transition region $\left[-196^{\circ} \mathrm{C} ;-60^{\circ} \mathrm{C}\right]$.

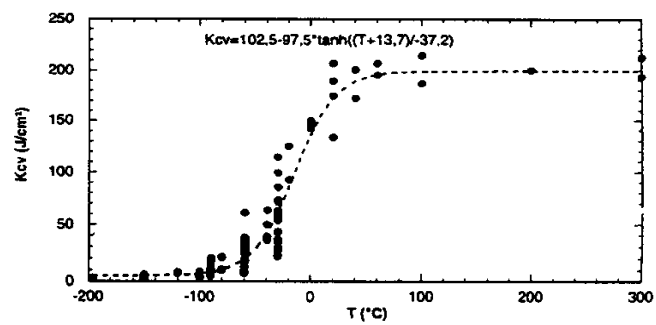

Fig.2. Resilience curve of the 16MND5 bainitic steel [2; 
In order to determine the mechanical properties and the fracture mechanisms of the 16MND5, a series of tensile tests is performed: several specimens are broken at various low temperatures which are reached by using liquid nitrogen and a heating resistor. Each test consists in a succession of loadings and unloadings leading to the failure of the specimen.

The tests are realized on a $20 \mathrm{kN}$ MTS machine, equiped with a liquid nitrogen-cooled chamber: the lengthening is determined by an extensometric gauge placed on the specimen. A cartography of the latter has been realized beforehand: several locations have thus been selected, according to their importance for the study of the behavior and the damaging mechanisms of the material. At each step of the loading, they are observed with a SEM, in order to determine the evolution of the damaging process (nucleation/crack-growth, but also appearance of slip lines) as well as the nature of the sites responsible for the failure of the specimen.

\subsection{X-ray diffraction}

Diffraction experiments are performed with a Seifert XRD 3003 PTS diffractometer equiped with a point detector, a flat graphite monochromator and vertical Soller slits. The stress analysis is realized on the plane $\{220\}$ of the ferrite, by using a cobalt anticathode; they will afterwards be realized on the plane $\{211\}$ of the ferrite with a chromium anticathode, in order to have optimal results. A step width of $0,05^{\circ}$ and a measuring time of 24 seconds for each step, for $\varphi=0^{\circ}$ (which corresponds to the tensile direction) and 11 positions of $\psi$ between $-65^{\circ}$ and $65^{\circ}$, are chosen. This corresponds to a ten hour manipulation, for each stress determination: figure 3 shows the $2 \theta=f\left(\sin ^{2} \psi\right)$ curve and the diffraction peaks obtained for a $6,5 \%$ pre-stretched specimen at $-60^{\circ} \mathrm{C}$. The residual stresses in the ferrite $\sigma_{\text {ferrite }}^{\text {IR }}$ (plane $\{220\}$ ) are calculated for an initial angle $\theta_{0}=$ $123,929^{\circ}$, and the $\sin ^{2} \psi$ are obtained thanks to an isotropic traitment $(E=210000 \mathrm{MPa}$ and $v=0,3)$.

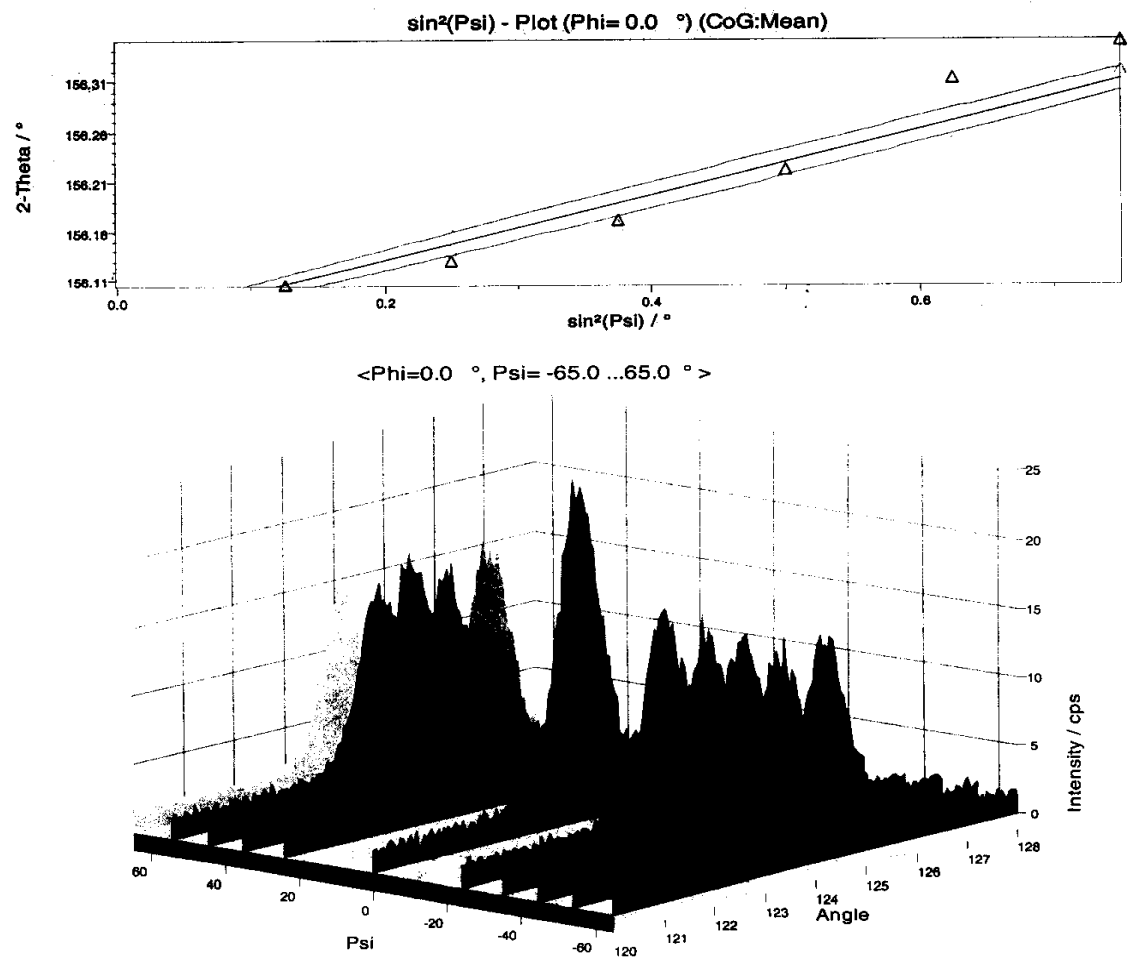

Fig. 3. $2 \theta$ vs. $\sin ^{2} \Psi$ curve and diffraction peaks obtained for a $6,5 \%$ pre-stretched specimen - tensile test at $-60^{\circ} \mathrm{C}$ 


\section{Stress distribution and discussion}

The volume fraction of cementite precipitates being too small to take any measures, the values of the residual stresses in this phase are deduced by using the following hypothesis (eq.1) on the macroscopic scale:

$$
\sigma^{\mathrm{I}}=\mathrm{f}_{\text {ferrite }} \cdot \sigma_{\text {ferrite }}^{\mathrm{I}}+\mathrm{f}_{\text {cementite }} \cdot \sigma_{\text {cementite }}^{\mathrm{I}}
$$

As seen in figure $4, \sigma^{\mathrm{I}}$ is given by the tensile curve. After each unloading, $\sigma^{\mathrm{I}}=0$, so that $\sigma^{\mathrm{IR}}$ cementite can be calculated (eq.2):

$$
\mathrm{f}_{\text {ferrite }} \cdot \sigma_{\text {ferrite }}^{\mathrm{IR}}+\mathrm{f}_{\text {cementite }} \cdot \sigma_{\text {cementite }}^{\mathrm{IR}}=\mathbf{0}(2)
$$

$\mathbf{f}_{\text {ferrite }}$ and $\mathbf{f}_{\text {cementite }}$ respectively represent the volume fraction of ferrite and cementite in the material.

$\sigma_{\text {ferrite }}^{\mathrm{I}}$ and $\sigma_{\text {cementite }}^{\mathrm{I}}$ are obtained in the following way (eq. 3 and eq.4):

$$
\begin{aligned}
& \sigma_{\text {ferrite }}^{\mathrm{I}}=\sigma^{\mathrm{I}}+\sigma^{\mathrm{IR}} \text { ferrite } \\
& \sigma_{\text {cementite }}^{\mathrm{I}}=\sigma^{\mathrm{I}}+\sigma_{\text {cementite }}^{\mathrm{IR}}
\end{aligned}
$$

where $\sigma^{\mathrm{IR}}{ }_{\text {ferrite }}$ and $\sigma^{\mathrm{IR}}$ cementite are the residual stresses in each phase after unloading.

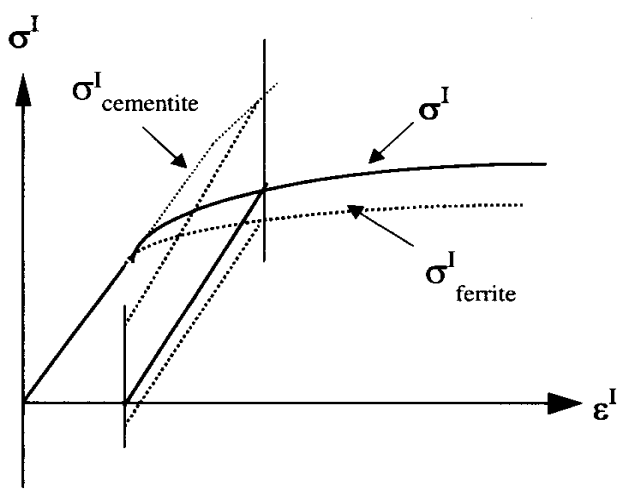

Fig.4. Internal stresses into the material

The stress states obtained at $-60^{\circ} \mathrm{C}$ and $-196^{\circ} \mathrm{C}$ are reported in table 2 . It can be noticed that the residual stresses show the ferritic phase is in compression, never exceeding $-150 \mathrm{MPa}$.

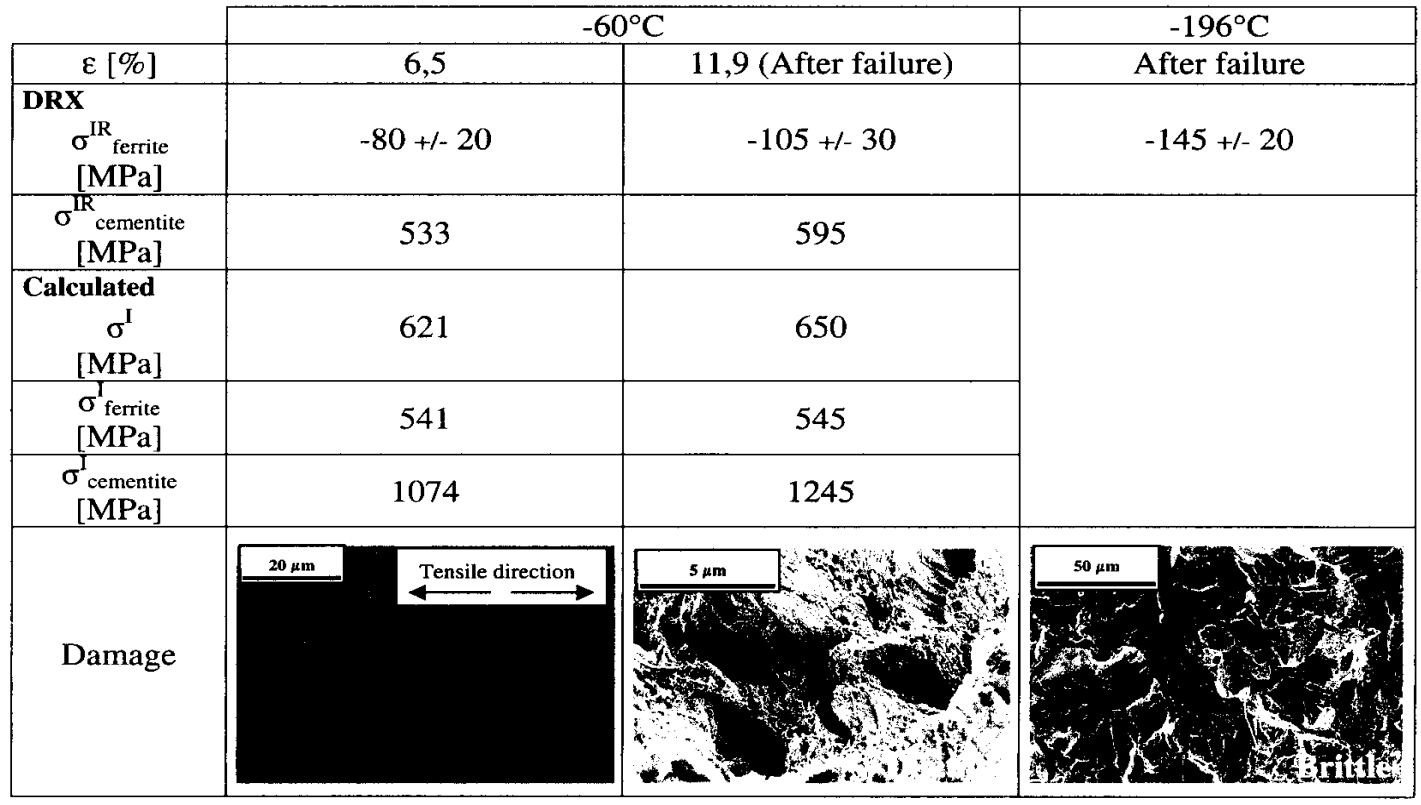

Table 2. Residual and internal stresses obtained at $-60^{\circ} \mathrm{C}$ and $-196^{\circ} \mathrm{C}$ for a tensile test $\left(f_{\text {cementite }}=0,15\right)$ 
One can deduce the stress distribution in each phase (ferrite and cementite) during the tensile test (fig.5).

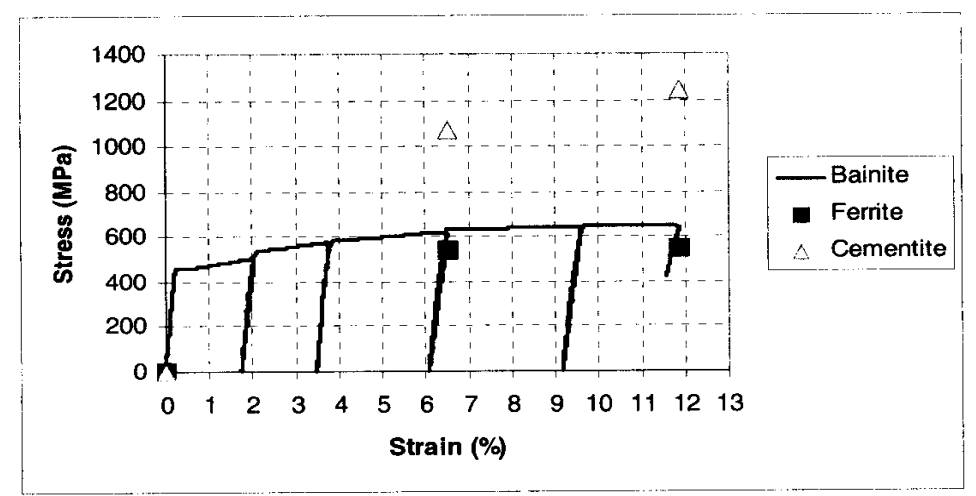

Fig.5. Stress distribution in each phase (ferrite and cementite) for a tensile test at $-60^{\circ} \mathrm{C}$

At $-60^{\circ} \mathrm{C}$ under loading, the cementite reaches values of the order of $1600 \mathrm{MPa}$, while the ferrite does not go beyond $545 \mathrm{MPa}$ : thus, $\sigma_{\text {cementite }}^{\mathrm{I}}>\sigma^{\mathrm{I}}>\sigma_{\text {ferrite. }}^{\mathrm{I}}$. Contrary to $\sigma_{\text {cementite, }}^{\mathrm{I}} \sigma_{\text {ferrite }}^{\mathrm{I}}$ reaches values close to the macroscopic stress $\sigma^{\mathrm{I}}$, since the discrepancy does not exceed $150 \mathrm{MPa}$. This difference can be more important in other materials such as Uranus $45 \mathrm{~N}$ or duplex steel [8]: it can thus reach more than $400 \mathrm{MPa}$. These results, especially the high stress value observed for cementite (expressing a higher yield stress), are similar to those obtained by Belassel for a pearlitic steel [9].

The SEM observation of the specimen during the tensile testing at $-60^{\circ} \mathrm{C}$ and $-80^{\circ} \mathrm{C}$ shows that the $\mathrm{MnS}$ inclusions are already cracked in several places as early as a $1 \%$ strain: then, they undergo a strong decohesion that can lead to the ejection of some of them out of the material (fig.6). However, this has little influence on the whole matrix stress state, since their volume fraction is quite small: this agrees with the obtained internal stress values, since no significant stress-relief can be noticed considering the stresses obtained in the ferritic phase by XRD.

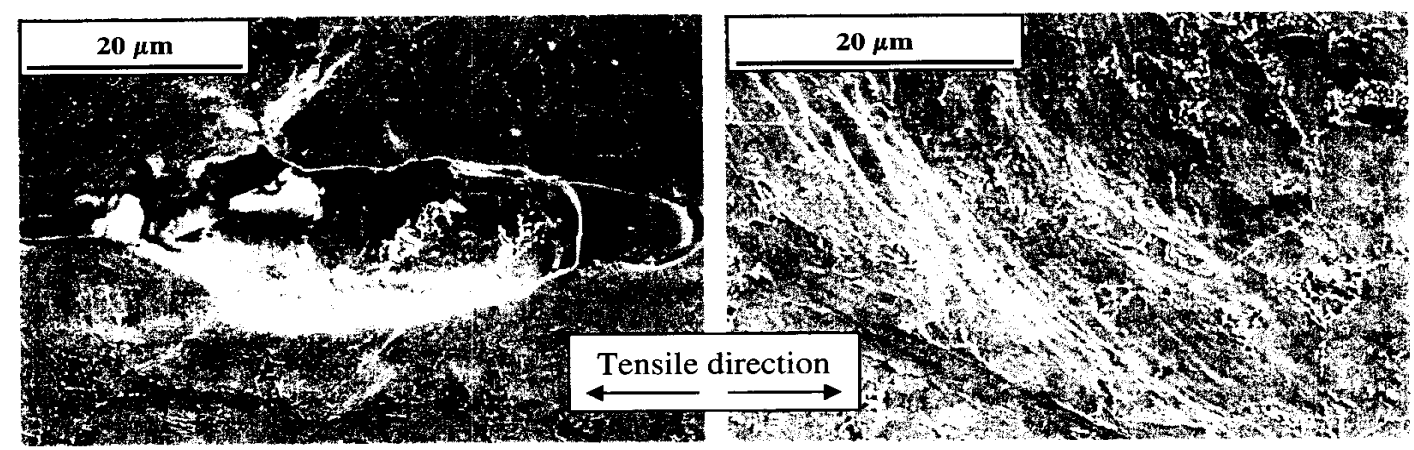

Fig.6. SEM micrographs showing a MnS cracked and the apparition of slip lines

The stress $\sigma^{\mathrm{IR}}$ ferrite is consistent with the plastic activity observed with the SEM: slip lines soon appears and their intensity increases with the strain (Fig.6). Cleavage is not observed at these temperatures, whereas it is the most important fracture mechanism at $-196^{\circ} \mathrm{C}$. Indeed, the stress states are higher at this temperature $-\left|\sigma_{\text {Ferrite }-196^{\circ} \mathrm{C}}^{\mathrm{R}}\right|>\mid \sigma^{\mathrm{IR}}$ Ferrite $-60^{\circ} \mathrm{C} \mid$, as seen in table $1-$, so that a critical cleavage stress criterion [10] seems to be reached more quickly. This criterion can be of a crystallographic nature: Electron Back-Scattered Diffraction (EBSD) has shown that cleavage fracture occured on $\{100\}$ ferrite planes [5]. 


\section{Conclusion}

The experiments have shown that the residual stresses in the ferritic phase increase with strain: at temperatures superior to $-80^{\circ} \mathrm{C}$, they do not seem to be high enough to induce cleavage. However, many in-situ experiments remain to be done at temperatures ranging from $-80^{\circ} \mathrm{C}$ to $-196^{\circ} \mathrm{C}$ in order to determine the fracture mechanisms for each one: a small tensile machine will be thus placed right into the SEM and on the diffractometer so that microscopic observations and residual stress measurements will be made without unloading. Microgrids [11] will also be placed on specimens on which EBSD mapping will have been realized: this will enable to couple local strain fields with misorientation angles, in order to establish significant damage criteria. Besides, the XRD will be used to determine the average stress states into all the grains having the same crystallographic orientation, thanks to the crystallite-group method: two orientations will be thus defined, one prone to cleavage and the other to plasticity.

All these types of measurements enable to supply a model of behavior and damage with data, on a scale inferior to the macroscopic curve (for example, a critical shear stress $\tau_{c}$ is defined for each phase): concurrently with the experimental characterization, it takes into account, in particular, the effects of temperature, crystalline plasticity and ferrite-cementite interactions.

\section{Acknowledgements}

The authors are grateful to MTC department of EDF research center - especially Renaud Masson and Gilles Rousselier - for supporting this study.

\section{References}

[1] Kim M.C., Oh Y.J. and Hong J.H.: Scripta Materialia Volume 43 Issue 3 (2000), p. 205-211

[2] Renevey S.: Approches globale et locale de la rupture dans le domaine de transition fragile-ductile d'un acier faiblement allié (Rapport de thèse de l'Université Paris XI Orsay, France 1997).

[3] Rossoll A.: Détermination de la ténacité d'un acier faiblement allié à partir de l'essai Charpy instrumenté (Rapport de thèse de l'Ecole Centrale de Paris, France 1998).

[4] Carassou S.: Déclenchement du clivage dans un acier faiblement allié: rôle de l'endommagement ductile localisé autour des inclusions (Rapport de thèse de l'Ecole Nationale Supérieure des Mines de Paris, France 1999).

[5] Lambert A.: Rupture par clivage de microstructures d'aciers bainitiques obtenues en conditions de soudage (Rapport de thèse de l'Ecole Nationale Supérieure des Mines de Paris, France 2001).

[6] Narström T. and Isacsson M.: Materials Science and Engineering Volume A271 (1999), p. 224-231.

[7] Ruppersberg H.: Materials Science \& Engineering A Volume 224 Issues 1-2 (1997), p. 61-68.

[8] Inal K., Gergaud P., François M. and Lebrun J.L.: Scandinavian Journal of Metallurgy Volume $8 \mathrm{n}^{\circ} 4$ (1999), p. 139-150.

[9] Belassel M.: Etude de la distribution des contraintes d'ordre I et II par diffraction des rayons $X$ dans un acier perlitique (Rapport de thèse de l'Ecole Nationale Supérieure des Arts et Métiers Centre de Paris, France 1994).

[10] M'Cirdi L., Lebrun J.L., Inal K. and Barbier G.: Acta Materialia Volume 49 Issue 18 (2001), p. 3879-3887.

[11] Allais L., Bornert M., Bretheau T. and Caldemaison D.: Acta Metallurgica Volume 42 Issue 11 (1994), p.3865-3880. 